\title{
ASSESSING SUSTAINABILITY OF PADDY FARMERS IN PERI-URBAN KHULNA: AN APPLICATION OF FARMER SUSTAINABILITY INDEX
}

(D) Rashmia Sultana ${ }^{1+}$
(i) Kazi Humayun
Kabir $^{2}$
(iD Kamrul Hasan
(D) Sardar Al Imran
(i) Md. Ayatullah
Khan $^{5}$

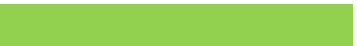

Article History

Received: 30 June 2021 Accepted: 2 December 2021 Published: 28 December 2021

\section{Keywords}

Sustainable agriculture Farming activities Sustainable development Paddy farming

Farmer sustainability index.

\author{
${ }^{1,4}$ Post Graduate Student, Development Studies Discipline, Khulna \\ University, Bangladesh. \\ 'Email: rashmiakhan2013@gmail.com Tel: +8801630808534 \\ ${ }^{4}$ Email:abirimran26@gmail.com Tel: +8801757278811 \\ 'Associate Professor, Development Studies Discipline, Khulna University, \\ Bangladesh; PhD Researcher, Department of Urban Planning and Design, \\ The University of Hong Kong. \\ ${ }^{2}$ Email:kabirkth@gmail.com Tel: +8801713825538 \\ ${ }^{3}$ Associate Professor, Development Studies Discipline, Khulna University, \\ Bangladesh. \\ ${ }^{3}$ Email: kamrulhasan1423@gmail.com Tel: +8801717868653 \\ ${ }^{5}$ Graduate Student, Development Studies Discipline, Khulna University, \\ Bangladesh. \\ ${ }^{5}$ Email: ayatullah.ku@gmail.com Tel: +8801940025595
}

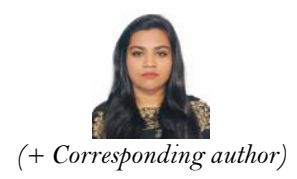

(+ Corresponding author)

\begin{abstract}
Association of sustainability agriculture and farming practices is somehow closely connected. There are necessary different farming practices for both adjusted and unadjusted PFSI measurement. The study observes practices of paddy farming and if farmers are practicing agriculture sustainably by estimating PFSI in three villages of Gutudia union. The objective is to spot the present agricultural practices and accessible sustainable practices, to examine the sustainability degree at field beneath the present paddy farming systems using PFSI and additionally to identify recommendations. The unit of analysis is 50 farmers and measured on a scale of 0 to 100 and also through Saltiel, Bauder, and Palakovich (1994) index. The results discovers that the average sustainability level which is presumably quite unsustainable this shows the necessity for more extension of correct practices. Chi-square analysis shows that the level of farmers' awareness toward sustainable agriculture and positive attitude are considerably different with the level of PFSI.
\end{abstract}

Contribution/Originality: This study is one of very few studies which has investigated the sustainability of the paddy farmers of that particular area where, most of the people are dependent on agricultural activities for their livelihoods. An established formula has been used to fine the level of sustainability.

\section{INTRODUCTION}

Sustainable agriculture in many components of the earth can be an issue of spirited dialogue and great interest (Crews, Mohler, \& Power, 1991). Sustainable agriculture is printed as a system that, "over the long run, enhances environmental quality and conjointly the resource base on which agriculture depends; provides for basic human food and fiber needs; is economically viable; and enhances the quality of life for farmers and society as a whole" (Ikerd, 1993; Lowrance, Hendrix, \& Odum, 1986).

Studies show that farmers in developing countries lacks information regarding sustainability systems (Mishra et al., 2018). The study is chiefly regarding Khulna, Bangladesh, the foremost offer of economic gain of Khulna is 
agriculture $56.56 \%$, non-agricultural manual laborer $4.04 \%$, industry $1.72 \%$, commerce $15.20 \%$, etc. (Rahman \& Routray, 1998). Bangladesh's overall agricultural policy objective is to expand and diversify agriculturally production and to maintain food security, significantly with regard to sustaining independence in rice (Faroque, Kashem, \& Bilkis, 2011; Walker \& Sarkar, 1996).

As a low-lying country, Bangladesh can expect natural disasters that can cut the productivity of many seed varieties long used by its farmers (Faroque et al., 2011), and for this Bangladesh is losing 1.75 percent of its arable land each year - faster than its population growth of 1.5 percent (Ali, 2007; Islam \& Talukder, 2017). This means that by 2025, it will has to feed 19 million more people with considerably less land. As a part of Bangladesh thus mensuration sustainability in agriculture for peri-urban Khulna is extremely vital and for this Paddy Farmer Sustainability Index (PFSI) that's usually a relative live of sustainability, with scores appointed by scrutinizing individual farmers' practices to those utilized by all farmers involving in paddy production (Akter, Parvin, Mila, \& Nahar, 2019). As we all know doing agriculture sustainably helps to reduce misuse of resources and heaps of production for larger generations (Tilman, Cassman, Matson, Naylor, \& Polasky, 2002) it feels necessary to measure present sustainability speed. Changing technologies tend to be the most efficient force for driving increasing agricultural productivity and agricultural development promotion in OECD countries (Lee, 2005; Viatte, 2001).

Bangladesh agriculture has achieved momentous structural changes, the revolution has taken place which is still evolving in response to natural calamities, changes in the sociopolitical situation, urbanization, expanding technologies that are new and improvised opportunities for agriculture in a rural area, changing both sector and macro policies (Ali, 2007; Hossain, 1984; Lázár et al., 2015; Mondal, 2010; Rahman \& Salim, 2013; Rahman, 1998; Wennergren, 2019). Bangladesh economy is mainly driven by agriculture and also hoped to remain the same in the foreseeable future but still, the agricultural income and productivity are much lower compared to the nonagricultural sector (Hossain, 2005; Muhammad, 2006; Rahman, 2017; Uddin, 2015).

About $75 \%$ of the total cropped area and over $80 \%$ of the total irrigated area is planted to paddy (Haque, Pramanik, Biswas, Iftekharuddaula, \& Hasanuzzaman, 2015). However, the country is now producing about 36.2 million tons to feed her 164.7 million people (Haggblade, Hazell, \& Dorosh, 2007; Naher, 1997). This indicates that the growth of paddy production was much faster than the growth of population (Papademetriou, 2000). This increased paddy production has been possible largely due to the adoption of modern rice varieties on around $66 \%$ of the paddy land which contributes to about $73 \%$ of the country's total rice production as a result of sustainable agriculture (Jagadish et al., 2012; Miah, Ahmed, \& Mustafi, 2004; Shah, Grant, \& Stocklmayer, 2014). However, there is no reason to be complacent. The population of Bangladesh is still growing by two million every year and may increase by another 30 million over the next 20 years and, Bangladesh will require about 27.26 million tons of rice for the year 2020 (Baffes \& Gautam, 2001; Kabir \& Chowdhury, 1982; Streatfield \& Karar, 2008).

This study is based on creating a "Sustainability Index" for the paddy farmers in peri-urban Khulna, to see the level of sustainability that existed in the field and find out what needs to be done for required sustainability. This type of work hasn't been done before for Khulna and this makes this work unique and this is a research gap. It is visible that being a new work will help other researchers who are interested in this field.

\section{METHODOLOGY}

\subsection{Material and Methods}

The paddy farmers of three villages of Gutudia Union of Dumuria Upazila that are Uttar Bill Pabla, Purba and Line Bill Pabla has been interviewed personally through a field survey in this study. Dumuria Upazila has 14 Union and Gutudia is one of them with the coverage of 141118-acre area of Dumuria (Banglapedia, 2007). Where almost $65.43 \%$ of people earn their livelihood from agriculture with landowners $69.36 \%$, landless $30.64 \%$ and the main crop is paddy (BBS, 2011). Since Gutudia's paddy sector holds the large potential to produce more paddy this study can 
be strategically very helpful. This study used purposive random sampling for the collection of data from the respondents (Guarte \& Barrios, 2006). Among the 66 agro-based families then using the simple snowball sampling method, 50 farmers of different ages and religions has been interviewed as all agricultural practices has almost the same characteristics (Dragan \& Isaic-Maniu, 2013). With reference to the Hayati and Karami (1996) "Measuring Agricultural Sustainability", work that reviewed measurements of sustainable agriculture from different aspects, components, indicators, and the interactions among them. This research has also displayed the farm and national level scales and dimensions of sustainability. Another journal published by Terano, Mohamed, Shamsudin, and Latif (2015) conducted in 2013, focuses on the practices of paddy farmers of Kelantan and assesses that the paddy farmers are practicing agriculture sustainably or not by using the PFSI. For the unadjusted PFSI, a value range between 0 to 100 as an index has been adjusted to compare the numerical scale and the range used was suggested by Taylor, Mohamed, Shamsudin, Mohayidin, and Chiew (1993); Shamsudin, Chiew, Mohamed, Mohayidin, and Taylor (1994). Agricultural practices like; seeding, land preparation, fertilizer application, water management, pest control, weed control, etc. were used and then the PFSI scores has been calculated using these farm practices. Each and every farm practice gives a value score of non-sustainable and sustainable practice (See Table 2 for details). From the checklist, 27 farm practices that start from land preparation and ends with pest control all these values has been summed up so as to get the total indexed sustainability scores. And for the adjusted PFSI, an operational index suggested by Hayati and Karami (1996) has been used for measuring agricultural sustainability trend at the farm level. The parameters measured in that method are those factors that intervene in the crop production process and could has a positive effect on the process. For this same purpose an index which is constituted of seven components has been presented (Saltiel et al., 1994) (See Table 1 for details).

\subsection{Indicators for Measurement}

Zhen and Routray (2003) has proposed operational indicators (Figure 1) that can measure agricultural sustainability based on the three components; economic, social and environmental and there are some indicators mentioned under these components. The three components along with the indicators are summarized below-

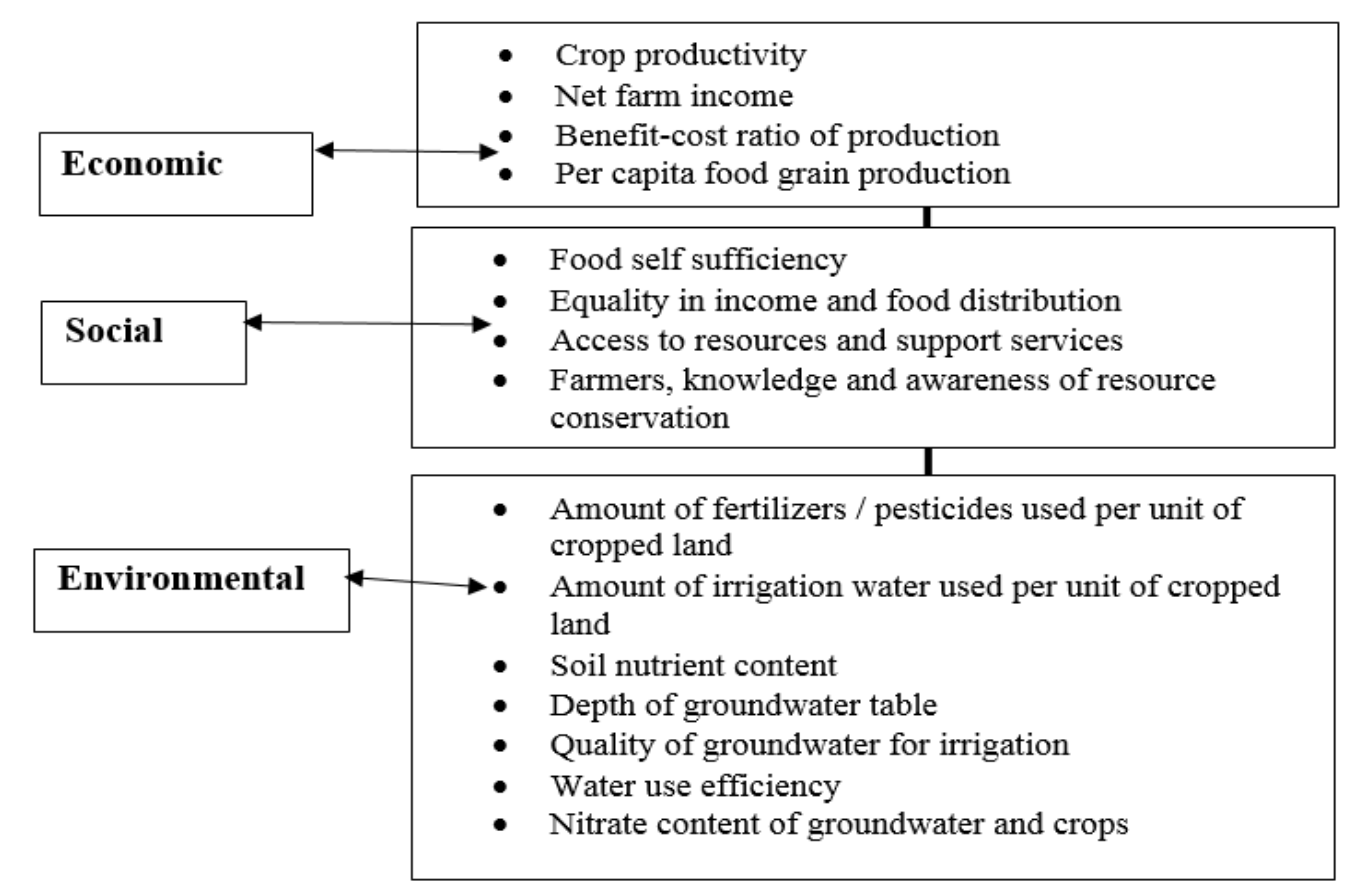

Figure-1. Proposed agricultural indicators for measuring sustainability.

Source: Zhen and Routray (2003). 


\subsection{Levels for Index Measurement}

This study is referred to Taylor et al. (1993) and Shamsudin et al. (1994) FSI measurements and applied them to paddy farming practices to estimate PFSI value and range as suggested by them. In order to facilitate the interpretation of the PFSI scores, the indexes were adjusted to fall within a range of 0 to 100 as quotient. The continuous PFSI values were assigned to six discrete sustainability categories, with the following range of index values (Shamsudin et al., 1994):

- $\quad$ Sustainable: > 70.0;

- $\quad$ Somewhat sustainable: 60.1 - 70.0;

- Intermediate: 50.1 - 60.0;

- Possibly unsustainable: 40.1 - 50.0;

- Possibly quite unsustainable: 40.0 - 20.0; and

- Possibly very unsustainable: $<=20.0$.

\subsection{Formula of Adjusted Measurement}

Hayati and Karami (1996) suggested an operational index to measuring agricultural sustainability trend in farm level. The parameters measured in that method are those factors that intervene in the crop production process and could has positive effect in the process. The measurement is summarized in below equation-

\section{$\mathrm{S}=\left[\sum_{i=1}^{8} X i, \sum_{i=1}^{3} Y j\right]$}

Source: Hayati and Karami (1996).

$\mathrm{S}=$ Trend of sustainability

$\mathrm{X} 1=$ Average of crop production per hectare.

$\mathrm{X}_{2}=$ Execution of crop rotation

$\mathrm{X} 3$ = Usage of organic manures.

$\mathrm{X}_{4}=$ Usage of green manures.

$\mathrm{X} 5=$ Usage of crop stubble.

$\mathrm{X} 6=$ Usage of conservational plough.

$\mathrm{X} 7=$ Trend of change in water resources (at the farm).

$\mathrm{X} 8=$ Trend of change in soil resources (at the farm).

$\mathrm{Y} 1$ = Amount of pesticides, herbicides, and fungicides consumption in the farm in one cultivational season.

$\mathrm{Y}_{2}=$ Amount of nitrate fertilizer consumption per $1 \mathrm{t}$ of crop production.

Y3 = Amount of phosphate fertilizer consumption per $1 \mathrm{t}$ of crop production.

In fact, parameters of $\mathrm{X} 1$ till X8 could lead to more sustainability if they increase and parameters of Y1 till Y3 could lead to unsustainability if they increase. Thus the below equation is established:

$\mathrm{S}=\sum_{i=0}^{7} X i-\sum_{i=0}^{3} Y j$

In order to measure agricultural sustainability at the farm level, Saltiel et al. (1994) presented an index which is constituted of seven components. They are: cultivation of sustainable crops, conservational cultivation, crop rotation, diminishing of pesticides and herbicides usage, soil mulching, and use of organic fertilizers.

\subsection{Formula for Unadjusted Measurement}

Throughout the entire process of farming practices in growing paddy, there six main processes that are selected to be abstaining PFSI in this study (Table 2). The minimum (0) and maximum (1) unadjusted scores and score range for each group practice are as follows (Table 3) (Terano et al., 2015). 
Table-1. Adjusted formula components on study area perspective.

\begin{tabular}{|c|c|}
\hline$\overline{\mathrm{X} \text { Components }}$ & Y Components \\
\hline $\mathrm{X} 1=$ Average of crop production per hectare & \multirow{7}{*}{$\begin{array}{l}\text { Y1 }=\text { Amount of pesticides, herbicides, and fungicides } \\
\text { consumption in the farm in one cultivational season } \\
\text { Y2 = Amount of nitrate fertilizer consumption per } 1 \mathrm{t} \text { of crop } \\
\text { production } \\
\text { Y3 = Amount of phosphate fertilizer consumption per } 1 \mathrm{t} \text { of } \\
\text { crop production }\end{array}$} \\
\hline $\mathrm{X} 2$ = Execution of crop rotation & \\
\hline $\mathrm{X} 4 \mathrm{l}=$ Usage of green manures & \\
\hline X3 = Usage of organic manures & \\
\hline $\mathrm{X} 5=$ Usage of crop stubble & \\
\hline X6 = Usage of conservational plough & \\
\hline $\mathrm{X} 7=$ Trend of change in water resources (at the farm) & \\
\hline
\end{tabular}

Table-2. Paddy farmer sustainability index values.

\begin{tabular}{l|l}
\hline Land preparation : & $\mathbf{0}$ to $\mathbf{3}$; range $\mathbf{3}$ points, \\
\hline Seedling : & -1 to 1 ; range 2 points, \\
\hline Fertilizer application : & -1 to $5 ;$ range 6 points, \\
\hline Water management : & 0 to $2 ;$ range 2 points, \\
\hline Weed control : & -4 to $15 ;$ range 19 points, and \\
\hline Pest control: & -4 to $7 ;$ range 11 points. \\
\hline
\end{tabular}

Table-3. Production practices of the study area included in the unadjusted Farmer Sustainability Index (FSI).

\begin{tabular}{|c|c|c|c|}
\hline Farming Practices & Amount/Frequency & Max. Score & Min. Score \\
\hline $\begin{array}{l}\text { 1. Land preparation } \\
\text { 1.1. First/Primary Plowing }(6-8 \text { weeks, } \\
\text { Max. depth } 10 \mathrm{~cm}) \\
\text { 1.2. Second Plowing (3 weeks before } \\
\text { planting, Max. depth } 5-7.5 \mathrm{~cm}) \\
\text { 1.3. Soil to a depth of } 10 \mathrm{~cm} \text { to } 15 \mathrm{~cm}\end{array}$ & $\begin{array}{l}\text { Yes }=1, \mathrm{No}=0 \\
\mathrm{Yes}=1, \mathrm{No}=\mathrm{O} \\
\mathrm{Yes}=1, \mathrm{No}=0\end{array}$ & $\begin{array}{l}1 \\
1 \\
1\end{array}$ & $\begin{array}{l}\mathrm{O} \\
\mathrm{O} \\
\mathrm{O}\end{array}$ \\
\hline $\begin{array}{l}\text { 2. Seeding } \\
\text { 2.1. Amount of Seeding (140kg per/ha) }\end{array}$ & $\begin{array}{l}\text { below } 130 \mathrm{~kg} / \mathrm{ha}=0 \\
130-150 \mathrm{~kg} / \mathrm{ha}=1 \\
150 \text { and } \mathrm{above} / \mathrm{ha}=-1\end{array}$ & -1 & 1 \\
\hline $\begin{array}{l}\text { 3. Timing } \\
\text { 3.1. Transplantation }(15-20 \text { days after } \\
\text { direct-seeding) } \\
\text { 3.2. } \begin{array}{l}\text { Transplantation } \\
\text { direct-seeding })\end{array} \\
\text { 3.3. Amount of fertilizer, } 1 \mathrm{~kg} / \text { acre }\end{array}$ & $\begin{array}{l}\text { Not following }=0 \\
\text { Within } 15-20 \text { days }=+110 \\
\text { Not following }=0 \\
\text { Within } 35-40 \text { days }=+110 \\
1 \mathrm{~kg} / \text { acre }=+1 \text {, } \\
\text { Less than } 1 \mathrm{~kg} / \text { acre }=0 \\
\text { Exceeding amount }(\text { above } 101 \%)=-1 \text {, }\end{array}$ & $\begin{array}{l}1 \\
1 \\
1 \\
1 \\
1\end{array}$ & $\begin{array}{c}0 \\
0 \\
0 \\
0 \\
-1\end{array}$ \\
\hline $\begin{array}{l}\text { 4. Water management } \\
\text { 4.1. Following irrigation schedule } \\
\text { 4.2. Salinity Check }\end{array}$ & $\begin{array}{l}\text { Yes }=1, \text { No }=0 \\
\text { Yes }=1, \text { No }=0\end{array}$ & $\begin{array}{l}1 \\
1\end{array}$ & $\begin{array}{l}\mathrm{O} \\
\mathrm{O}\end{array}$ \\
\hline 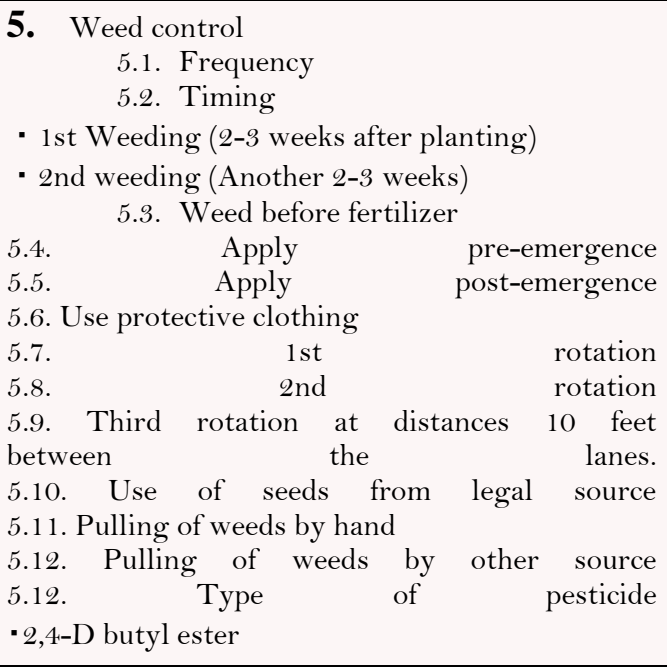 & $\begin{array}{l}\text { O or } 1 \text { time }=1,2 \text { times }=0, \text { above } 3 \\
\text { times }=-1 \\
\text { Not following schedule }=0, \text { within } 3- \\
5 \text { days }=+1 \\
\text { Not following schedule }=0 \\
\text { Yes }=1, \text { No }=0 \\
\text { Yes }=1, \text { No }=0 \\
\text { Yes }=1, \text { No }=0 \\
\text { Yes }=1, \text { No }=0 \\
\text { Yes }=1, \text { No }=0 \\
\text { Yes }=1, \text { No }=0 \\
\text { Yes }=1, \text { No }=0 \\
\text { Yes }=1, \text { No }=0 \\
\text { Yes }=1, \text { No }=0 \\
\text { Yes }=1, \text { No }=0 \\
\text { Yes }=1, \text { No }=0 \\
\text { Yes }=1, \text { No }=0 \\
\text { Yes }=1, \text { No }=0\end{array}$ & $\begin{array}{l}2 \\
1 \\
2 \\
1 \\
1 \\
1 \\
1 \\
1 \\
1 \\
1 \\
1 \\
1 \\
1 \\
1 \\
1 \\
1 \\
1 \\
1\end{array}$ & $\begin{array}{c}-1 \\
0 \\
0 \\
0 \\
0 \\
0 \\
0 \\
0 \\
0 \\
0 \\
0 \\
0 \\
0 \\
0 \\
0 \\
0 \\
0 \\
0\end{array}$ \\
\hline 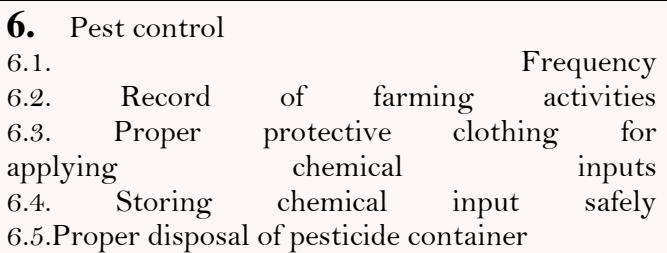 & $\begin{array}{l}\text { o or } 1 \text { time }=1,2 \text { times }=0, \text { above } 3 \\
\text { times }=-11-1 \\
\text { Yes }=1, \text { No }=0 \\
\text { Yes }=1, \mathrm{No}_{0}=0 \\
\text { Yes }=1, \mathrm{No}=0 \\
\text { chemical disposal }=1, \text { others }=0\end{array}$ & $\begin{array}{l}1 \\
1 \\
1 \\
1 \\
1\end{array}$ & $\begin{array}{l}-1 \\
0 \\
0 \\
0 \\
0\end{array}$ \\
\hline
\end{tabular}




\section{RESULTS AND DISCUSSIONS}

\subsection{Adjusted Farmer Sustainability Index}

This result belongs to group five that is, "Possibly Quite Unsustainable". This group has a range of 20-40 and the result is 33.33, which is somehow in between these numbers. Here the researcher has used seven components for variable $\mathrm{X}$ and three components for variable $\mathrm{Y}$. And every variable has the highest value of 3, medium value of 2 , and lowest value of 1 . As the highest value is 3 for the 10 compound variables of $\mathrm{X}$ and $\mathrm{Y}$. And that is why the sum total value is 30 for all the variables, where $\mathrm{X}=16$ and $\mathrm{Y}=6$. Then every component's results has been subdivided by 30 and multiplied by 100, as all the variables and components are $100 \%$ of their class (Table 4).

Every component has been collected from the field level that's why they are called the raw data and that's why they vary in number, as some are $\mathrm{kg}$ per hector, some are mound per hector etc. (Table 4). To bring them to the same category, every component has been calculated into the unit of $\mathrm{kg} / \mathrm{Katha}$. That's how the calculations has been calculated and the result of 33.33 and the fact that it belongs to the group of "Possibly Quite Unsustainable". And this result will help further for agricultural researchers and other officials to take actions to push the levels to an upper class and ultimately to achieve sustainability.

Table-4. Calculation Table of Adjusted FSI.

\begin{tabular}{|c|c|c|c|c|c|}
\hline \multirow[t]{2}{*}{ Variables } & \multirow[t]{2}{*}{ Raw Data } & \multirow[t]{2}{*}{ Per/Katha } & Level & \multirow[t]{2}{*}{ Result } & \multirow[t]{2}{*}{ Calculations } \\
\hline & & & $\begin{array}{c}\text { High }=3, \\
\text { Medium }=2, \text { Low }=1\end{array}$ & & \\
\hline $\mathrm{X}_{1}$ & $\begin{array}{l}80 \text { mounds } \\
\text { (hybrid } \\
\text { per/acre) }\end{array}$ & $\begin{array}{c}40.49 \\
(\mathrm{Kg} / \text { Katha })\end{array}$ & $\begin{array}{c}\mathrm{L}=35 \mathrm{~kg}< \\
\mathrm{M}=35-45 \mathrm{Kg} \\
\mathrm{H}=<45 \mathrm{Kg}\end{array}$ & 2 & $\begin{array}{c}2 / 30 * 100= \\
6.67 \%\end{array}$ \\
\hline $\mathrm{X}_{2}$ & 2 times & $\begin{array}{c}\text { Highest Practice } \\
\text { in Bangladesh is } \\
3 \text { times }\end{array}$ & $\begin{array}{l}\mathrm{L}=1 \text { times } \\
\mathrm{M}=2 \text { times } \\
\mathrm{H}=3 \text { times }\end{array}$ & 2 & $\begin{array}{c}2 / 30 * 100= \\
6.67 \%\end{array}$ \\
\hline $\mathrm{X}_{3}$ & $1 \mathrm{~kg} /$ Katha & $\ldots \ldots$ & $\begin{array}{l}\mathrm{L}=1 \mathrm{~kg}< \\
\mathrm{M}=1 \mathrm{Kg} \\
\mathrm{H}=<1 \mathrm{~kg}\end{array}$ & 2 & $\begin{array}{c}2 / 30 * 100= \\
6.67 \%\end{array}$ \\
\hline $\mathrm{X}_{4}$ & $100 \%$ & ......... & $\begin{array}{c}\mathrm{L}=30 \%< \\
\mathrm{M}=30-60 \% \\
\mathrm{H}=<60 \%\end{array}$ & 3 & $3 / 30 * 100=10 \%$ \\
\hline $\mathrm{X}_{5}$ & 3 types & $\cdots \cdots$ & $\begin{array}{c}\mathrm{L}=\operatorname{Cow} 30 \%< \\
\mathrm{M}=\text { H.T. } 30-60 \% \\
\mathrm{H}=\text { P.T. }<60 \%\end{array}$ & 2 & $\begin{array}{c}2 / 30 * 100= \\
6.67 \%\end{array}$ \\
\hline $\mathrm{X}_{6}$ & 3 types & $\ldots \ldots+\cdots \cdots \cdots$ & $\begin{array}{c}\mathrm{L}=\text { Rain } \\
\mathrm{M}=\text { Surface } \\
\mathrm{H}=\text { Ground }\end{array}$ & 3 & $3 / 30 * 100=10 \%$ \\
\hline $\mathrm{X}_{7}$ & $2 \%$ & $\ldots \ldots \ldots+\cdots \cdots$ & $\begin{array}{c}\mathrm{L}=1 \%< \\
\mathrm{M}=1 \% \\
\mathrm{H}=<1 \%\end{array}$ & 2 & $\begin{array}{c}2 / 30 * 100= \\
6.67 \%\end{array}$ \\
\hline
\end{tabular}

Table-4. Continue....

\begin{tabular}{|c|c|c|c|c|c|}
\hline Variables & Raw Data & Per/Katha & $\begin{array}{c}\text { Level } \\
\text { High }=3, \\
\text { Medium }=2, \text { Low }=1\end{array}$ & Result & Calculations \\
\hline $\mathrm{Y}_{1}$ & $5 \%$ (kg/Katha) & $\ldots \ldots \ldots \ldots \ldots$ & $\begin{array}{l}\mathrm{L}=.12 \mathrm{~kg}< \\
\mathrm{M}=.12 \mathrm{~kg} \\
\mathrm{H}=<.12 \mathrm{~kg}\end{array}$ & $\overline{2}$ & $1 / 30 * 100=3.33 \%$ \\
\hline $\mathrm{Y}_{2}$ & $150 \mathrm{~kg} / \mathrm{ha}$ & $1.90 \mathrm{~kg} /$ Katha & $\begin{array}{l}\mathrm{L}=1.9 \mathrm{~kg}< \\
\mathrm{M}=1.9 \mathrm{~kg} \\
\mathrm{H}=<1.9 \mathrm{~kg}\end{array}$ & 2 & $\begin{array}{c}2 / 30^{*} 100= \\
6.67 \%\end{array}$ \\
\hline \multirow[t]{2}{*}{$\mathrm{Y}_{3}$} & $35.90 \mathrm{~kg} / \mathrm{ha}$ & $0.443 \mathrm{~kg} /$ Katha & $\begin{array}{l}\mathrm{L}=0.443 \mathrm{~kg}< \\
\mathrm{M}=0.443 \mathrm{~kg} \\
\mathrm{H}=<0.443 \mathrm{~kg}\end{array}$ & 2 & $\begin{array}{c}2 / 30^{*} 100= \\
6.67 \%\end{array}$ \\
\hline & & & Total & $\begin{array}{c}\mathrm{X}=16, \\
\mathrm{Y}=6\end{array}$ & \\
\hline
\end{tabular}

Note: H.T. $=$ Hand Tilling, P.T. $=$ Power Tilling. 
$\mathrm{S}=\sum_{\mathrm{i}=1}^{\mathrm{n}} \mathrm{Xi}-\sum_{\mathrm{i}=1}^{\mathrm{n}} \mathrm{Y}_{\mathrm{j}}^{\mathrm{j}}$

Source: (Hayati \& Karami, 1996)

$\mathrm{S}=\sum_{\mathrm{i}=1}^{7} \mathrm{Xi}-\sum_{\mathrm{i}=1}^{3} \mathrm{Yj}$

$\mathrm{S}=16-6$

$=10 / 30 * 100=33.33$

\subsection{Unadjusted Farmer Sustainability Index}

\subsubsection{Hypotheses for Unadjusted FSI}

After the researcher has estimated the PFSI value for taking into an insight under the sustainability practices of paddy farmers, the researcher has also analyzed chi-square for measuring the association statistically between the socio-demographic variables such as; level of education, age, job type, farm size; and attitude \& awareness on sustainable farming practices in collaboration with the PFSI values. For identifying and examining the difference of the farmers' characteristics significantly in different categories of PFSI; the researcher has formulated the hypotheses that are given below;

- $\mathrm{H}_{0}$ : There is no association between PFSI value and the age of the respondent farmers that tend to be statistically significant. The hypothesis is that farmers who are more aged are less sustainable than the farmers with younger age; as they are doing the same practices for the last 25-50 years. And it is also hypothesized that the factor might cause change resistance and for being sustainable.

- $\mathrm{H}_{0}$ : There is no statistically significant association between the education level of the farmers and the PFSI value. It is hypothesized that farmers who are more literate than those who are comparatively less educated are supposed to be more sustainable in farming practices as they tend to has more knowledge of sustainability from books or campaigns in their schools and colleges.

- $\mathrm{H}_{0}$ : There is no statistically significant association between the size of the farm and the PFSI value. It is hypothesized the bigger farms are tend to has low sustainability practices in their farms; as it is difficult to maintain large farms than to maintain small-sized ones as they are more tedious and expensive.

- $\mathrm{H}_{0}$ : There is no statistically significant association between PFSI value and between full-time and part-time farmers as the job types are different. It is hypothesized that it is easy for the full-time farmers to maintain and control their farms and practices more accurately than the part-time farmers as they spend more time and give more attention in their farms and has a greater understanding.

- $\mathrm{H}_{\mathrm{o}}$ : There is no statistically significant association between the awareness of the farmers for practicing agriculture and farming activities sustainably and the PFSI values. It is hypothesized that farmers who are more aware and has positive attitude towards sustainability can result in more sustainable agricultural practices.

- $\mathrm{H}_{0}$ : There is no statistically significant association between PFSI values and the attitude of the farmers for practicing and making agriculture and farming practices more sustainable. It is hypothesized that farmers with a positive response for sustainable agriculture can encourage farmers to practice agriculture sustainably.

And it shows that, if the chi-square test shows no statistical difference between characteristics of the farmers, attitude and awareness, and PFSI values, then there is no statistical association between the variables, and the test failed to reject the null hypothesis. 


\subsubsection{Chi-Square Analysis between PFSI Value Categories and Farmers' Characteristics}

Table 5 shows the association of farmers' characteristics (age, education level, farm size, and types of job), farmer's awareness, and attitude towards sustainable agriculture with PFSI values statistically.

The chi-square test for this study indicates that there are no significant differences among the farm size $\left(\mathrm{X}^{2}=\right.$ $0.404, \mathrm{P}<0.817)$, age $\left(\mathrm{X}^{2}=2.069, \mathrm{P}<0.723\right)$, and education level $\left(\mathrm{X}^{2}=0.317, \mathrm{P}<0.853\right)$ in practicing farming practices in sustainability level. Thus regardless of their education, age, education, types of job $\left(\mathrm{X}^{2}=0.325, \mathrm{P}<\right.$ 0.850), and firm size, well-distributed sustainability can be noticed. And this proves that which means to say that even though the farmer is younger, small firm size, and educated, sustainable agricultural practices are practiced by none. On the contrary, farmers' awareness $\left(\mathrm{X}^{2}=5.878, \mathrm{P}>0.049\right)$ and attitude $\left(\mathrm{X}^{2}=7.460, \mathrm{P}>0.037\right)$ towards sustainable agriculture also showed to have a statistical association with PFSI values.

Table-5. Chi-square analysis of PFSI value to different categories of the Study Area.

\begin{tabular}{l|c|c|c}
\hline Chi-Square & Value & Df & $\begin{array}{c}\text { Asymptotic } \\
\text { Significance }\end{array}$ \\
\hline Age of the Respondents & 2.069 & 4 & 0.723 \\
\hline Education of the Respondents & 0.317 & 2 & 0.853 \\
\hline Farm Size part-time/full time jobs beside paddy & 0.404 & 2 & 0.817 \\
\hline $\begin{array}{l}\text { Types of Job (P25 } \\
\text { farming) }\end{array}$ & 2 & 0.850 \\
\hline Awareness: Has you ever heard about sustainability? & 5.878 & 2 & $0.049^{* * *}$ \\
\hline $\begin{array}{l}\text { Attitude: Is sustainable farming seems important for paddy } \\
\text { production? }\end{array}$ & 7.460 & 2 & $0.37^{*}$ \\
\hline
\end{tabular}

\subsubsection{Cross-Tabulation of Farmers' Characteristics among PFSI Value Categories}

Looking into deeper more details, Table 6 shows tables of cross-tabulation to explore if there are any differences in response to the result of chi-square analysis across multiple categories. The Cross-tabulation of PFSI values of this study shows that there are $36(72.11 \%)$ of the studied farmers who have been replied to be aware of sustainable agriculture/farming out of 50 total farmers that the researcher has been studied in the survey area. Awareness of the farmers about sustainable agriculture, their frequency distribution is supposed to be categorized into higher PFSI values. Also, 24 $(47.6 \%)$ of the 50 paddy farmers who think that sustainable agriculture is important in paddy production are categorized into upper PFSI value while attitudes that is tend to be negative towards sustainable agriculture, tend to cause lower PFSI values. And the overall, chi-square analysis explored that the statistical association between PFSI and farmers' awareness, and also attitudes towards suitable agriculture. In spite of the farmers' characteristics such as educational level, age, types of job, and firm size and the PFSI value has an association with farmers' mindset such as awareness and attitude that sustainable agriculture is an important practice for rice farming and that is also statistically.

Table-6. Cross-tabulation of farmers' characteristics among PFSI value categories.

\begin{tabular}{l|c|c|c}
\hline \multirow{2}{*}{} & \multicolumn{3}{|c}{ PFSI (Paddy Farmers Sustainability Index) } \\
\cline { 2 - 4 } & \multicolumn{4}{|c}{} & $\mathbf{4 0 - 4 9 . 9}$ & $>\mathbf{5 0}$ \\
\hline Age of the Respondents & $10.33 \%$ & $6.20 \%$ & $8.30 \%$ \\
\hline Below 25 Years old & $10.12 \%$ & $16.19 \%$ & $8.10 \%$ \\
\hline 26-45 Years old & $17.60 \%$ & $11.74 \%$ & $11.74 \%$ \\
\hline Above 46 Years old
\end{tabular}


Table-6. Continue...

\begin{tabular}{l|c|c|c}
\hline \multirow{2}{*}{} & \multicolumn{3}{c}{ PFSI (Paddy Farmers Sustainability Index) } \\
\cline { 2 - 4 } & $<\mathbf{4 0}$ & $\mathbf{4 0 - 4 9 . 9}$ & $>\mathbf{5 0}$ \\
\hline Education of the Respondents & $28.20 \%$ & $9.80 \%$ & $11.50 \%$ \\
\hline Until Elementary & $23.43 \%$ & $17.73 \%$ & $29.50 \%$ \\
\hline After Secondary & \multicolumn{3}{|c}{} \\
\hline
\end{tabular}

Table-6. Continue...

\begin{tabular}{l|c|c|c}
\hline \multirow{2}{*}{ Farm Size of the Respondents } & \multicolumn{2}{c}{ PFSI (Paddy Farmers Sustainability Index) } \\
\cline { 2 - 4 } Below Average & $\mathbf{4 4 0}$ & $\mathbf{4 0 - 4 9 . 9}$ & $>\mathbf{5 0}$ \\
\hline Above Average & $13.72 \%$ & $10.25 \%$ & $21.92 \%$ \\
\hline
\end{tabular}

Table-6. Continue...

\begin{tabular}{|c|c|c|c|}
\hline & \multicolumn{3}{|c|}{ PFSI (Paddy Farmers Sustainability Index) } \\
\hline & $<40$ & $40-49.9$ & $>50$ \\
\hline \multicolumn{4}{|c|}{ Job Type of the Respondents } \\
\hline Part-Time Farmers & $5.74 \%$ & $19.68 \%$ & $13.78 \%$ \\
\hline Full-Time Farmers & $14.22 \%$ & $18.29 \%$ & $12.19 \%$ \\
\hline
\end{tabular}

Table-6. Continue...

\begin{tabular}{l|c|c|c}
\hline \multirow{2}{*}{} & \multicolumn{3}{c}{ PFSI (Paddy Farmers Sustainability Index) } \\
\cline { 2 - 4 } & $\mathbf{< 4 0}$ & $\mathbf{4 0 - 4 9 . 9}$ & $\mathbf{5 5 0}$ \\
\hline Awareness: Has you ever heard about sustainability? & $20.03 \%$ & $34.05 \%$ \\
\hline Yes & $18.03 \%$ & $3.98 \%$ & $11.95 \%$ \\
\hline No & $11.95 \%$ & \\
\hline
\end{tabular}

Table-6. Continue...

\begin{tabular}{l|c|c|c}
\hline \multirow{2}{*}{} & \multicolumn{3}{|c}{ PFSI (Paddy Farmers Sustainability Index) } \\
\cline { 2 - 4 } & $\mathbf{< 4 0}$ & $\mathbf{4 0 - 4 9 . 9}$ & $>\mathbf{5 0}$ \\
\hline Attitude: Is sustainable farming seems important for paddy production? \\
\hline Yes & $9.92 \%$ & $17.85 \%$ & $19.83 \%$ \\
\hline No & $26.25 \%$ & $8.08 \%$ & $18.17 \%$ \\
\hline
\end{tabular}

As twenty-five lakh increased population per year has been eating up all the achievements in agricultural production. Consequently, people's standard of living is declining and the number of people below the poverty level is increasing. For this, the researcher has selected the topic to measure the current level of sustainability that is existing in Gutudia and how much it is needed to push so that this large number of mouths can be given proper food. The main analysis for this research is to find out adjusted and Unadjusted "FSI" results and the overall sustainability status of this area regarding agriculture. For this, the researcher has used Hayati's formula for adjusted measurement which is calculated based on the results of summation $\mathrm{Xi}$ and that is subtracted by summation of Yj (Hayati \& Karami, 1996) and this measurement can be seen in chapter three of this research paper. The result shows a number that is 33.33 and this number belongs to the category of "Possible quite unsustainable" and it is also can be seen that there is much scope to improve this situation and push it to become "Sustainable". To become more sustainable, rotating crops and embracing diversity; Planting cover crops, reducing or eliminating tillage; applying integrated pest management (IPM); integrating livestock, and crops and adopting agroforestry practices can be major solutions for desired success.

Cross-tabulation to explore if there are any differences in response to the result of chi-square analysis across multiple categories of the farmers' basic characteristics has been also analyzed. The Cross-tabulation of PFSI values 
of this study shows that there are $36(72.11 \%)$ of the studied farmers who has been replied to be aware of sustainable agriculture/farming out of 50 total farmers that the researcher have been studied in the survey area. Awareness of the farmers about sustainable agriculture, their frequency distribution is supposed to be categorized into higher PFSI values. Also, 24 (47.6\%) of the 50 paddy farmers who think that sustainable agriculture is important in paddy production are categorized into upper PFSI value while attitudes that is tend to be negative towards sustainable agriculture, tend to cause lower PFSI values. And the overall, chi-square analysis explored that the statistical association between PFSI and farmers' awareness, and also attitudes towards suitable agriculture. In spite of the farmers' characteristics such as educational level, age, types of job, and firm size and the PFSI value has an association with farmers' mindset such as awareness and attitude that sustainable agriculture is important practice for rice farming and that is also statistically.

The growth rate of paddy production is declining, on the contrary land and water resources for paddy production are becoming scarce and Gutudia Union villages under Dumuria Upazila are also facing and going to face this even deeper in the near future. For this, the food security of paddy consumers depends on greater national, regional, and international efforts and investments toward achieving sustainable production increases. Policymakers also need the information of paddy production and also on improved technologies that are available for sustainable intensification of paddy production in order to formulate appropriate policies for supporting paddy production.

\section{CONCLUSION}

This study reveals that the utmost difficulty in monitoring and measuring the sustainability of agriculture is that it is not a static but a dynamic concept which needs skills and observations on a higher level that will help to adapt to change (Röling \& Pretty, 1997). Measuring sustainability at the farm level supposed to be the most precise method, where policies of the higher level (e.g. national) affect the activities of the lower levels (e.g. farm), thought by most of the scholars (Steer, 2008). So understanding the levels of each level's interaction is necessary as each level helps to find out its mechanisms explanations in the level below, and the significance of the level above. The results reveal that most of the paddy farmers are still not aware of the importance of the concepts of agricultural sustainability and environmental conservation. As there were no such differences in the age, education level, type of job, and size of the farm in their practices for sustainability but there are different variables that varies in terms of their awareness and attitude for sustainability in agriculture and environmental conservation. And it is important to focus on those farmers who are aware and has a positive attitude for agricultural sustainability should be the top priority so that they can become sustainable farmers. And this will be of great difficulty to boost the sustainability level among the paddy farmers for the extension officers. The results of the study are quite alarming and immediate steps need to be taken to educate paddy farmers through extension programs and training.

Funding: This study received no specific financial support.

Competing Interests: The authors declare that they have no competing interests.

Acknowledgement: All authors contributed equally to the conception and design of the study.

\section{REFERENCES}

Akter, T., Parvin, M. T., Mila, F. A., \& Nahar, A. (2019). Factors determining the profitability of rice farming in Bangladesh. Journal of the Bangladesh Agricultural University, 17(1), 86-91. Available at: https://doi.org/10.3329/jbau.v 17i 1.40668.

Ali, A. M. S. (2007). Population pressure, agricultural intensification and changes in rural systems in Bangladesh. Geoforum, 38(4), 720-738. Available at: https://doi.org/10.1016/j.geoforum.2006.11.028.

Baffes, J., \& Gautam, M. (2001). Assessing the sustainability of rice production growth in Bangladesh. Food Policy, 26(5), 515542. Available at: https://doi.org/10.1016/s0306-9192(01)00019-7.

Banglapedia. (2007). Cultural Survey Report of Dumuria Upazila. Banglapedia. 
BBS. (2011). Bangladesh population census: BBS.

Crews, T. E., Mohler, C. L., \& Power, A. G. (1991). Energetics and ecosystem integrity: The defining principles of sustainable agriculture. American Journal of Alternative Agriculture, 6(3), 146-149. Available at: https://doi.org/10.1017/s0889189300004124.

Dragan, I.-M., \& Isaic-Maniu, A. (2013). Snowball sampling completion. Journal of Studies in Social Sciences, 5(2), $160-177$.

Faroque, M., Kashem, M., \& Bilkis, S. (2011). Sustainable agriculture: A challenge in Bangladesh. International Journal of Agricultural Research, Innovation and Technology, 1(1-2), 1-8. Available at: https://doi.org/10.3329/ijarit.v1i1-2.13922.

Guarte, J. M., \& Barrios, E. B. (2006). Estimation under purposive sampling. Communications in Statistics-Simulation and Computation, 35(2), 277-284. Available at: https://doi.org/10.1080/03610910600591610.

Haggblade, S., Hazell, P. B., \& Dorosh, P. A. (2007). Sectoral growth linkages between agriculture and the rural nonfarm economy. Transforming the Rural Nonfarm Economy: Opportunities and Threats in the Developing World, 141-182.

Haque, M., Pramanik, H., Biswas, J., Iftekharuddaula, K., \& Hasanuzzaman, M. (2015). Comparative performance of hybrid and elite inbred rice varieties with respect to their source-sink relationship. The Scientific World Journal, 1-11. Available at: https://doi.org/10.1155/2015/326802.

Hayati, D., \& Karami, E. (1996). A proposed scale to measure sustainability at farm level in socio-economic studies. Paper presented at the First Agricultural Economic Conference of Iran, Zabol, Iran.

Hossain, M. (1984). Agricultural development in Bangladesh: A historical perspective. The Bangladesh Development Studies, 29-57.

Hossain, M. (2005). Growth of the rural non-farm economy in Bangladesh: Determinants and impact on poverty reduction. Paper presented at the Proceedings of International Conference Titled'Rice is life: Scientific Perspectives for the $21 \mathrm{st}$ Century.

Ikerd, J. E. (1993). The need for a system approach to sustainable agriculture. Agriculture, Ecosystems \& Environment, 46(1-4), 147160. Available at: https://doi.org/10.1016/0167-8809(93)90020-p.

Islam, S. F., \& Talukder, R. K. (2017). Projections of food demand and supply in Bangladesh: Implications on food security and water demand. International Journal of Sustainable Agricultural Management and Informatics, 3(2), 125-153. Available at: https://doi.org/10.1504/ijsami.2017.10006559.

Jagadish, S., Septiningsih, E., Kohli, A., Thomson, M., Ye, C., Redona, E., \& Ismail, A. (2012). Genetic advances in adapting rice to a rapidly changing climate. Journal of Agronomy and Crop Science, 198(5), 360-373. Available at: https://doi.org/10.1111/j.1439-037x.2012.00525.x.

Kabir, M., \& Chowdhury, A. A. (1982). Population growth and food production in Bangladesh. Rural Demography, 9(1-2), 25-56.

Lázár, A. N., Clarke, D., Adams, H., Akanda, A. R., Szabo, S., Nicholls, R. J., \& Abedin, M. A. (2015). Agricultural livelihoods in coastal Bangladesh under climate and environmental change-A model framework. Environmental Science: Processes $\mathcal{E}^{\circ}$ Impacts, 17(6), 1018-1031. Available at: https://doi.org/10.1039/c4em00600c.

Lee, D. R. (2005). Agricultural sustainability and technology adoption: Issues and policies for developing countries. American Journal of Agricultural Economics, 87(5), 1325-1334. Available at: https://doi.org/10.1111/j.1467-8276.2005.00826.x.

Lowrance, R., Hendrix, P. F., \& Odum, E. P. (1986). A hierarchical approach to sustainable agriculture. American Journal of Alternative Agriculture, 1(4), 169-173. Available at: https://doi.org/10.1017/s0889189300001260.

Miah, N., Ahmed, A., \& Mustafi, B. (2004). Adopting modern rice technologies in flood-prone areas: Status, constraints, and opportunities. Rice Research and Development in the Flood-Prone Ecosystem, 171.

Mishra, B., Buddhi, G., Krishna, P., Neelam, P., Marion, S., Siddhartha, D., \& George, A. (2018). Adoption of sustainable agriculture practices among farmers in Kentucky, USA. Environmental Management, 1-13. Available at: https://doi.org/10.1007/s00267-018-1109-3.

Mondal, M. H. (2010). Crop agriculture of Bangladesh: Challenges and opportunities. Bangladesh Journal of Agricultural Research, 35(2), 235-245. Available at: https://doi.org/10.3329/bjar.v35i2.5886.

Muhammad, A. (2006). Globalisation and economic transformation in a peripheral economy: The Bangladesh experience. Economic and Political Weekly, 1459-1464. 
Naher, F. (1997). Green revolution in Bangladesh: Production stability and food self-sufficiency. Economic and Political Weekly, A84-A89.

Papademetriou, M. (2000). Rice production in the Asia-Pacific region: Issues and perspectives. RAP Publication (FAO).

Rahman, S., \& Routray, J. (1998). Regional variation in agricultural development in Bangladesh and policy implications. Bangkok, Thailand: Asian Institute of Technology.

Rahman, S., \& Salim, R. (2013). Six decades of total factor productivity change and sources of growth in Bangladesh agriculture (1948-2008). Journal of Agricultural Economics, 64(2), 275-294. Available at: https://doi.org/10.1111/1477-9552.12009.

Rahman, S. (1998). Socio-economic and environmental impacts of technological change in Bangladesh agriculture. Doctoral Dissertation.

Rahman, M. (2017). Role of agriculture in Bangladesh economy: Uncovering the problems and challenges. International Journal of Business and Management Invention, 6(7), 36-46.

Röling, N., \& Pretty, J. N. (1997). Extension's role in sustainable agricultural development. Improving Agricultural Extension: A Reference Manual, 181-191.

Saltiel, J., Bauder, J. W., \& Palakovich, S. (1994). Adoption of sustainable agricultural practices: Diffusion, farm structure, and profitability 1. Rural Sociology, 59(2), 333-349. Available at: https://doi.org/10.1111/j.1549-0831.1994.tbo0536.x.

Shah, M., Grant, W., \& Stocklmayer, S. (2014). Adoption of hybrid rice in Bangladesh: Farm level experience.

Shamsudin, M. N., Chiew, E. F. C., Mohamed, Z. A., Mohayidin, M. G., \& Taylor, D. C. (1994). Farmers' production practices and sustainable development: The case of English cabbage production in Cameron Highlands. Malaysian Journal of Agricultural Economics (Jurnal Ekonomi Pertanian Malaysia)(Malaysia).

Steer, A. (2008). Achieving sustainable development and promoting development cooperation: United Nations Publications.

Streatfield, P., \& Karar, Z. (2008). Population challenges for Bangladesh in the coming decades. Journal of Health, Population, and Nutrition, 26(3), 261-272. Available at: https://doi.org/10.3329/jhpn.v26i3.1894.

Taylor, D. C., Mohamed, Z. A., Shamsudin, M. N., Mohayidin, M. G., \& Chiew, E. F. (1993). Creating a farmer sustainability index: A Malaysian case study. American Journal of Alternative Agriculture, 8(4), 175-184. Available at: https://doi.org/10.1017/s0889189300005403.

Terano, R., Mohamed, Z., Shamsudin, M. N., \& Latif, I. A. (2015). Farmers sustainability index: The case of paddy farmers in state of Kelantan, Malaysia. Journal of the International Society for Southeast Asian Agricultural Sciences, 21(1), 55-67.

Tilman, D., Cassman, K. G., Matson, P. A., Naylor, R., \& Polasky, S. (2002). Agricultural sustainability and intensive production practices. Nature, 418(6898), 671-677. Available at: https://doi.org/10.1038/nature01014.

Uddin, M. M. M. (2015). Causal relationship between agriculture, industry and services sector for GDP growth in Bangladesh: An econometric investigation. Journal of Poverty, Investment and Development, 8.

Viatte, G. (2001). Adopting technologies for sustainable farming systems: an OECD perspective. Paper presented at the Paper read at Adoption of Technologies for Sustainable Farming Systems Wageningen Workshop Proceedings.

Walker, M., \& Sarkar, A. (1996). The development of a national agricultural extension policy in Bangladesh. European Journal of Agricultural Education and Extension, 3(2), 85-95. Available at: https://doi.org/10.1080/13892249685300221.

Wennergren, E. B. (2019). Agricultural development in Bangladesh: Prospects for the future: Routledge.

Zhen, L., \& Routray, J. K. (2003). Operational indicators for measuring agricultural sustainability in developing countries. Environmental Management, 32(1), 34-46. Available at: https://doi.org/10.1007/s00267-003-2881-1.

Views and opinions expressed in this article are the views and opinions of the author(s), International Journal of Sustainable Agricultural Research shall not be responsible or answerable for any loss, damage or liability etc. caused in relation to/arising out of the use of the content. 